\title{
Characterization of Erwinia chrysanthemi from a Bacterial Heart Rot of Pineapple Outbreak in Hawaii
}

Wendy S. Kaneshiro, Department of Plant and Environmental Protection Sciences (PEPS), University of Hawaii, Honolulu 96822; Maren Burger, Biologische Chemie, University of Applied Sciences Mannheim, Germany; and Benjamin G. Vine, Asoka S. de Silva, and Anne M. Alvarez, PEPS, University of Hawaii

\begin{abstract}
Kaneshiro, W. S., Burger, M., Vine, B. G., de Silva, A. S., and Alvarez, A. M. 2008. Characterization of Erwinia chrysanthemi from a bacterial heart rot of pineapple outbreak in Hawaii. Plant Dis. 92:1444-1450.

The first reported outbreak of bacterial heart rot of pineapple (Ananas comosus var. comosus) in Hawaii occurred in December 2003. Of immediate concern was the differentiation of heart rot caused by Erwinia chrysanthemi from a soft rot caused by E. carotovora subsp. carotovora because of regulatory issues. Presumptive identifications of the isolated bacteria were made using bacteriological tests (including reactivity with an Erwinia-specific monoclonal antibody, E2) and compared with identifications obtained by two general methods: carbon source utilization profiling (Biolog) and 16S rDNA sequence analysis. The panel of bacteriological tests consistently differentiated E. chrysanthemi from E. carotovora subsp. carotovora and other nonquarantine organisms. BOX-polymerase chain reaction fingerprint patterns further differentiated the pineapple-isolated E. chrysanthemi strains from those obtained from other plants and irrigation water. Pineapple leaf inoculations revealed that only E. chrysanthemi from pineapple produced watersoaking and rot similar to that observed on the original symptomatic plants, thus identifying these strains as the causal agents of the outbreak. In this situation, where rapid identification of an unknown pathogen was necessary, standard bacteriological tests then available in the laboratory provided reliable differentiation of E. chrysanthemi from E. carotovora subsp. carotovora. Additional strain characterization is needed before the pineapple-isolated E. chrysanthemi strains can be classified into a species of the new genus Dickeya.
\end{abstract}

Pineapple (Ananas comosus var. comosus Coppens \& Leal) is a commercially important field crop in many tropical regions of Latin America, Asia, and Africa. Fruit production in Hawaii represents the entire commercial pineapple industry in the United States (excluding the territory of Puerto Rico), with a production value of $\$ 75.5$ million in 2006 (18). Due to the increased popularity of low-acid pineapple hybrids in the fresh fruit market, some Hawaiian plantations began importing planting stocks in the 1990 s to accelerate the replacement of less-desirable cultivars. Importation of tissue-cultured hybrid stocks or shoots

\section{Corresponding author: A. M. Alvarez E-mail: alvarez@hawaii.edu}

Current address of M. Burger: ALANTOS Pharmaceuticals AG, Heidelberg, Germany.

Current address of B. G. Vine: PAC/RIM Medical Technology and Supplies Corp., Honolulu, HI 96819.

* The $e$-Xtra logo stands for "electronic extra" and indicates that Figure 1 appears in color in the online edition.

Accepted for publication 26 June 2008.

doi:10.1094/PDIS-92-10-1444

(c) 2008 The American Phytopathological Society
In December 2003, a suspected bacterial heart rot outbreak was discovered in a Hawaiian pineapple field planted with suckers imported from Costa Rica and Honduras (29). This incident provoked talk of severe import restrictions by state and federal regulatory agencies if the infected plants were the inoculum source for the disease outbreak. In addition, suckers from the Philippines were considered another possible inoculum source because importations from that country also were ongoing.

Bacterial heart rot of pineapple was first reported in Malaysia (11) and has since been described in Costa Rica (4), Brazil, and the Philippines (23). Symptoms start as water-soaked zones on the centermost leaves surrounding the apical meristem, followed by the formation of brown streaks on the lamina and in mesophyll tissues. Frequently filled with gas, these blister-like lesions are characteristic of the disease (Fig. 1). Eventually, a light-brown exudate emerges from the blisters as leaves begin to rot. A few days after initial infection of the meristem and apical and lateral buds, the pineapple heart and stem can be easily detached from the belowground portion of the plant (11). In some instances, young pineapple fruit become (suckers) harvested from mature plants was the most expedient way to meet consumer demand, because it could take up to 10 years to harvest fruit if planting materials were to be multiplied solely from existing Hawaiian stock plants.

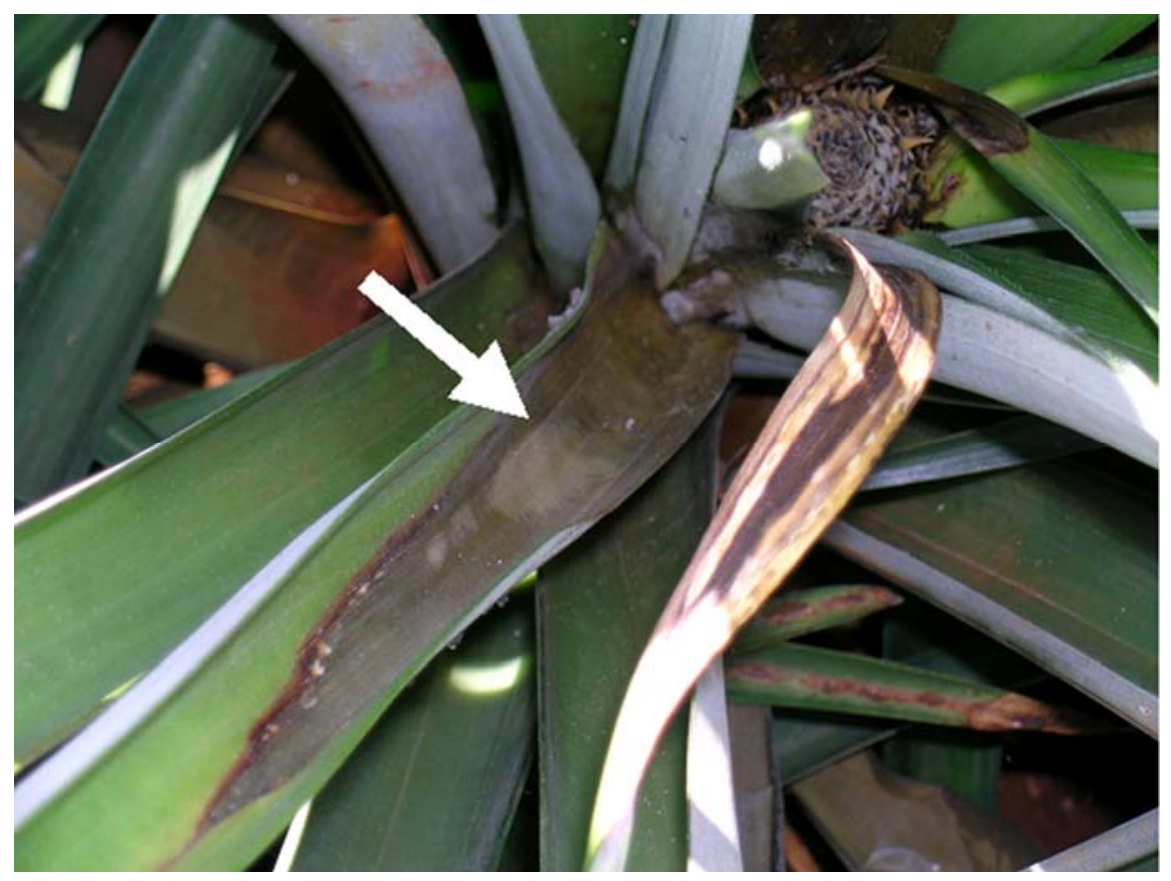

Fig. 1. Characteristic watersoaking originating from the heart with a gas-filled blister (arrow) caused by Erwinia chrysanthemi. 
latently infected, exhibiting a rapid soft rot and collapse at maturity (called pineapple fruit collapse; 14).

Exudate from collapsed infected fruit and leaves is the most likely source of inoculum for secondary spread and further infection through stomata or wounds (23). The bacteria also can be transmitted by wind, rain, and insects such as ants and pineapple souring beetles (23). The plant crop is more susceptible to the disease than the ratoon crop (which develops from shoots arising from the stem after the initial plant crop harvest), with young plants between 3 to 8 months old being most susceptible (11). Under optimal conditions, the time from initial symptom development to heart rot may occur in 1 to 2 weeks (23).

Erwinia chrysanthemi, the causal agent of both bacterial heart rot and fruit collapse of pineapple, and the closely related E. carotovora subsp. carotovora, are facultatively anaerobic bacteria that cause rot diseases on a wide variety of ornamental and crop plants worldwide (3). Originally classified as pectolytic Erwinia spp., both were later moved into the genus Pectobacterium as Pectobacterium chrysanthemi and $P$. carotovorum subsp. carotovorum, respectively. Recently, Samson et al. (24) proposed a major taxonomic change which separated E. chrysanthemi into five species under the new genus Dickeya. In that study, two strains of E. chrysanthemi isolated from pineapple were reclassified as Dickeya zeae and Dickeya sp. In the species description for $D$. dadantii, pineapple was also listed as a host plant. For the present, the pathogen affecting pineapple will be referred to as E. chrysanthemi until sufficient taxonomic studies on a larger collection of pineapple strains have been performed that can place the strains more definitively under the new nomenclature. For consistency in reporting, Erwinia nomenclature will also be used for the various subspecies of E. carotovora characterized in this study.

Both E. chrysanthemi and E. carotovora subsp. carotovora can survive in soil and can cause water-soaking and rot of pineapple hearts and leaves $(22,23)$. E. carotovora subsp. carotovora, however, only causes localized rotting when plants are wounded or grown under stress, whereas E. chrysanthemi can cause a systemic rot that moves from leaves to heart (or vice versa) regardless of stress factors. Whereas E. carotovora subsp. carotovora infections manifest immediately, E. chrysanthemi can form latent infections on planting stocks that can lead to major epidemics in areas not previously affected by disease. Thus, differentiation of $E$. chrysanthemi from $E$. carotovora subsp. carotovora is important for appropriate regulation of imported planting materials, especially in areas where the disease is not known to exist.

E. chrysanthemi has been reported previously in Hawaii on ornamentals and other crops, but not on pineapple before 2003 (29). The timing of this outbreak coincided with the importation and widespread planting of a relatively new hybrid pineapple, suggesting that either the pathogen had been introduced on latently infected planting stock or that local strains of $E$. chrysanthemi had become aggressive on the recently-imported pineapple hybrid. Identifying the source of inoculum (i.e., local or foreign) was essential for an appropriate regulatory response. The objectives of this study were to (i) assess generally used bacteriological, metabolic, and DNA-based identification methods for differentiation of E. chrysanthemi from $E$. carotovora subsp. carotovora and other saprophytes isolated from symptomatic pineapple tissues and (ii) verify the disease diagnosis and identify the specific strains involved in the outbreak.

\section{MATERIALS AND METHODS}

Bacterial isolation. Between 23 December 2003 and 19 October 2004, bacterial strains were isolated from 13 sets of samples consisting of leaves and stock tissues from a pineapple hybrid (no. 73114), irrigation water, and field soil. A set refers to a group of samples collected on the same date. Three sets consisted of mature 12-month-old plants from a single field started from suckers that had been shipped to Hawaii from Costa Rica (two sets) and Honduras (one set) and nine sets consisted of suckers imported from the Philippines which were tested prior to field planting. The last set consisted of irrigation water collected from two reservoirs supplying the affected field and soil collected from areas where symptomatic plants were originally observed. Samples from leaves and propagative stock were surface sterilized in $0.6 \%$ sodium hypochlorite for 3 to $5 \mathrm{~min}$, rinsed in sterile distilled water (SDW), and dried on paper towels before excising $5-\mathrm{mm}^{2}$ subsamples taken from the margins of the symptomatic tissues. Subsamples were macerated in sterile porcelain spot plates using a sterile glass rod and approximately $100 \mu \mathrm{l}$ of SDW. For colony differentiation, approximately $10 \mu \mathrm{l}$ of the resulting macerates were streaked onto a nonselective TZC medium (12), slightly modified from the original (20). Plates were incubated at $28^{\circ} \mathrm{C}$ for at least $48 \mathrm{~h}$ and then observed for colony formation. When subsamples yielded high concentrations of nontarget saprophytic bacteria on TZC medium, additional tissue samples were processed and macerates streaked directly onto semiselective Miller and Schroth (MS) medium (17). In some instances, several isolations were made from the same symptomatic plant to ensure isolation of the causal agent. Single suspect colonies were then selected from each of the agar plates and characterized to determine the consistency of results for each of the methods used. Samples $(10 \mathrm{ml})$ of irrigation water were filtered through $0.45-\mu \mathrm{m}$ mixed cellulose ester membranes (55 mm) using a fritted glass filter unit. Membranes were placed face-up on MS medium plates and incubated until colony development was observed. Field soil (10 g) was suspended in $50 \mathrm{ml}$ of sterile tap water and particulate matter was allowed to settle. Subsamples of the liquid phase were plated on MS medium and incubated to allow colony development. Pure cultures, obtained by restreaking isolates on TZC medium, were subsequently used for further characterization. Stock cultures were prepared in Luria-Bertani broth amended with $25 \%$ glycerol (vol/vol) and frozen at $-80^{\circ} \mathrm{C}$.

Bacteriological tests. Three bacteriological tests were used to differentiate presumptive Erwinia spp. from nonErwinia saprophytes: strand formation in the potassium hydroxide $(\mathrm{KOH})$ test to identify presumptive gram-negative $(\mathrm{KOH}$ positive) or gram-positive (KOH negative) organisms (27), glucose fermentation using OF medium with $1 \%$ glucose (vol/vol) (10), and pit formation on crystal violet sodium polypectate (CVP) medium to differentiate pectolytic bacteria from nonpectolytic bacteria (5). All tests were performed according to the respective authors or following the methods reported by De Boer and Kelman (7). Morphologies of single, isolated colonies on yeast dextrose calcium carbonate medium (YDC) (31) were also considered when making presumptive determinations. Two additional characteristics were used to further differentiate presumptive E. chrysanthemi from other Erwinia spp.: production of indigoidine on YDC medium and indole production detected by contact with pdimethylamino-cinnamaldehyde following growth on tryptone-tryptophan medium (10 $\mathrm{g}$ of tryptone, $1 \mathrm{~g}$ of L-tryptophan, and $15 \mathrm{~g}$ of agar per liter; 7). Nine E. chrysanthemi, E. carotovora subsp. carotovora, and E. carotovora subsp. atroseptica reference strains isolated from non-pineapple hosts were included in the bacteriological analysis for comparative purposes.

Indirect enzyme-linked immunosorbent assay. Presumptive identification of Erwinia spp. using an Erwinia-specific monoclonal antibody (MAb) E2 (clone 8258-B12-D7, generated against a local $E$. chrysanthemi strain from aglaonema; A. Alvarez, unpublished data) was attempted using an indirect enzyme-linked immunosorbent assay (ELISA). Bacteria were harvested from 48- to 72-h YDC plate cultures and incubated for at least $1 \mathrm{~h}$ in $0.01 \mathrm{M}$ phosphate-buffered saline (PBS) containing $0.5 \%$ formalin. Fixed cells were washed three times with $0.85 \% \mathrm{NaCl}$, resuspended in carbonate bicarbonate buffer (CBC; containing $1.59 \mathrm{~g}$ of $\mathrm{Na}_{2} \mathrm{CO}_{3}$ and $2.93 \mathrm{~g}$ of $\mathrm{NaHCO}_{3}$ per liter; $\mathrm{pH}$ 9.6) and diluted to $10^{8} \mathrm{CFU} / \mathrm{ml}$ (optical density at $\left.600 \mathrm{~nm}\left[\mathrm{OD}_{600}\right]=0.1\right)$. Subsamples 
(100 $\mu \mathrm{l})$ were pipetted into 96-well microtiter plates, dried overnight in a circulating air incubator at $37^{\circ} \mathrm{C}$, and then stored at $4^{\circ} \mathrm{C}$ until assayed.

ELISA procedures were based upon the method of Benedict et al. (1). Plates were flooded with boric acid buffer (containing $10.3 \mathrm{~g}$ of $\mathrm{H}_{3} \mathrm{BO}_{3}, 7.85 \mathrm{~g}$ of $\mathrm{NaCl}$, and $1.1 \mathrm{~g}$ of $\mathrm{NaOH}$ per liter) and incubated at room temperature for $15 \mathrm{~min}$, followed by two more washes without incubation. Wells were blocked using $200 \mu \mathrm{l}$ of $5 \%$ (wt/vol) powdered skim milk-PBS solution and incubated at room temperature for $30 \mathrm{~min}$. Wells were then sequentially incubated with MAb E2 (1:1000 dilution from ascites stock), rabbit anti-mouse globulin (1:1000 dilution), and Protein A-horseradish peroxidase (HRP) conjugate solution (1:2000; Bio-Rad, Hercules, CA), all prepared in $1.7 \%$ (wt/vol) milk-PBS. Plates were washed three times after each step. The peroxidase substrate was prepared by adding $20 \mathrm{mg}$ of 5 -aminosalicylic acid to 50 $\mathrm{ml}$ of PB-EDTA buffer (containing $0.651 \mathrm{~g}$ of $\mathrm{NaH}_{2} \mathrm{PO}_{4} \cdot 7 \mathrm{H}_{2} \mathrm{O}, 0.737 \mathrm{~g}$ of $\mathrm{Na}_{2} \mathrm{HPO}_{4}$, and $35 \mathrm{mg}$ of $\mathrm{Na}_{2}$ EDTA per liter; $\mathrm{pH} 6.8$ ) Immediately before use, $100 \mu \mathrm{l}$ of $3 \%$ $\mathrm{H}_{2} \mathrm{O}_{2}$ was added to the solution. After substrate addition, plates were incubated for 1 $\mathrm{h}$ at room temperature and then read at 450 nm using a Biolog MicroStation plate reader and the $\mathrm{KC} 4$ Microplate Data Analysis Software (Bio-Tek Instruments Inc., Winooski, VT). Wells that had identical or similar color development as the blank control were considered negative while samples that were twice the value of the negative control were considered positive.

Metabolic profiles (Biolog). Carbon source utilization patterns were obtained for selected isolates using the Biolog MicroLog Microbial Identification System (Biolog Inc., Hayward, CA) following the manufacturer's instructions. Data were analyzed using the MicroLog system release 4.20.04 software and either GN (version 6.01) or GP (version 6.11) databases.

16S rDNA sequence analysis. Genomic DNA was extracted using the Wizard Genomic DNA Purification Kit (Promega Corp., Madison, WI) following the manufacturer's protocol and stored at $4{ }^{\circ} \mathrm{C}$. The isolated DNA was quantified using a rapid agarose gel electrophoresis (RAGE) system (RGX-100 system; Cascade Biologics, Portland, OR) and 10 standard DNA concentrations (10 to $100 \mathrm{ng} / \mu \mathrm{l}$ ).

The partial 16S rRNA gene was amplified by polymerase chain reaction (PCR) using 10 pmol each of the universal primers fD1 and rP2 (30) and Platinum PCR SuperMix High Fidelity (Invitrogen Corp., Carlsbad, CA) using the cycling conditions of Kwon et al. (13) on an MJ Research PTC-100 Programmable Thermal Controller (Bio-Rad Laboratories Inc., Hercules, CA). The PCR product (approximately $1,450 \mathrm{bp}$ ) was resolved by electrophoresis using a $1.0 \%$ agarose gel and Tris-acetateEDTA (TAE) buffer.

Sequencing of PCR products using primer fD1 was performed by the Hawaii Marine Biology Sequencing Facility or at the Greenwood Biotechnology Core Facility (both located at the University of Hawaii). Between 500 and $650 \mathrm{bp}$ of the returned sequences were compared with the National Center for Biotechnology Information (NCBI) nucleotide database (nr/nt) using the BLASTN program (version 2.2.18) with default options to obtain species identifications. For strains identified as E. chrysanthemi during this screen, additional sequences were generated using primers rP2 and 1078R (5'-CCC AAC ATC TCA CGA CAC GAG-3') and single contigs of approximately 1,200 bp or more in length were assembled using the Sequencher program (version 4.7; Gene Codes Corp., Ann Arbor, MI). Contigs were compared with the NCBI nucleotide database using BLASTN to confirm initial identifications.

PCR using the ADE1/ADE2 primer set. All strains subjected to partial $16 \mathrm{~S}$ rDNA sequence analysis were tested with PCR using 10 pmol each of primers ADE1 and ADE2 to attempt amplification of an approximately 420-bp fragment of the pelADE pectate lyase gene cluster specific to E. chrysanthemi (19). Cycling conditions were as follows: $94^{\circ} \mathrm{C}$ for $2 \mathrm{~min}$; followed by 35 cycles of $94^{\circ} \mathrm{C}$ for $45 \mathrm{~s}$, $62^{\circ} \mathrm{C}$ for $45 \mathrm{~s}$, and $72^{\circ} \mathrm{C}$ for $2 \mathrm{~min}$, : and concluding with an extension at $72^{\circ} \mathrm{C}$ for 3 min (6). PCR products were visualized by electrophoresis.

Rep-PCR genomic fingerprinting. DNA fingerprints of representative strains were generated by rep-PCR using the BOXA1R primer (28) as previously described (15). Genomic DNA (50 ng/ $\mu \mathrm{l}$ ) was used as the template for all reactions. Subsamples $(6 \mu \mathrm{l})$ of the PCR reactions were resolved by electrophoresis using $1.5 \% \mathrm{TAE}$ agarose gels at room temperature for $5 \mathrm{~h}$ at $105 \mathrm{~V}$. Bands were stained with ethidium bromide and visualized using a UV transilluminator. Digital images of gels were acquired using the FOTO/Analyst Express Column and Hood Mount and FOTO/ Analyst PC Image software, version 5.00 (Fotodyne, Inc., Hartland, WI). Photos were generated using a Sony digital graphic printer (UP-D895; Sony Corp., Tokyo).

Pathogenicity tests. Nonsymptomatic 5-month-old hybrid pineapple plants were collected and transplanted to 3.8-liter pots in the greenhouse. Previously isolated bacterial strains were cultured from $-80^{\circ} \mathrm{C}$ stock on YDC medium for 2 to 3 days prior to inoculation and consisted of $18 \mathrm{E}$. chrysanthemi strains (including the 2 nonpineapple reference strains and the 1 strain from irrigation water), $1 E$. carotovora subsp. carotovora reference strain, $7 E$. carotovora strains (including 5 reference strains previously isolated in Hawaii), and
6 non-Erwinia saprophytes from pineapple. Immediately before use, strains were suspended in SDW and adjusted to $\mathrm{OD}_{600}$ $=0.1$ (approximately $10^{8} \mathrm{CFU} / \mathrm{ml}$ ). Three adjacent, shallow, vertical $1-\mathrm{cm}$ wounds were created in the middle of the test leaf using a sterile scalpel, and a minimum of $0.5 \mathrm{ml}$ of bacterial inoculum was applied into and over the wounds. A small piece of inoculum-saturated cotton was placed over the slits and held in place with transparent tape. A larger strip of clear plastic was then wrapped around the treated area to maintain moisture. Inoculated plants were kept in an enclosed acrylic container overnight to ensure high humidity. After $24 \mathrm{~h}$, inoculation sites were unwrapped and observed for symptom development. The plants were then placed on a greenhouse bench for further symptom development. Individual strains were inoculated into three leaves per plant. After $72 \mathrm{~h}$, leaves exhibiting light tan to brown puffy, water-soaked lesions around the leaf slits were considered positive reactions. Leaves with a light tan, discrete necrotic area around the leaf incisions but lacking the puffy, watersoaked regions were considered negative reactions. Leaves exhibiting positive reactions were removed from selected inoculated plants and bacteria were reisolated following the bacterial isolation procedure described above.

\section{RESULTS}

Bacterial isolation. Plants and suckers from the three importing countries exhibited a range of symptoms, including wrinkled and dry necrotic lesions (from Philippine plant samples), light tan or brown water-soaked blisters on the leaf lamina and broad, brown or dark brown watersoaked areas extending from the leaf down to the stock tissues in the plant heart (primarily from Costa Rican and Honduran plant samples). Very few bacteria (none facultatively anaerobic) were isolated from the dry necrotic lesions. High populations of bacteria with a variety of colony morphologies on TZC medium were isolated from the brown rotted leaf tissues. In contrast, the numerous colonies recovered from the tan water-soaked blisters and the symptomatic plant stocks were all morphologically similar on TZC medium. In all, 48 bacterial strains were characterized further: 26 strains from mature field plants (15 from Costa Rican stock plants and 11 from Honduran stock plants), 17 strains from Philippine suckers, and 5 facultatively anaerobic strains from irrigation water.

Characterization of Erwinia reference strains. The nine Erwinia reference strains used for comparison were all gramnegative, fermented glucose and produced pits on CVP medium, indicating pectolytic ability (Table 1). Only the two E. chrysanthemi strains were positive for both indigoidine and indole. The other Erwinia spp. 
did not produce indigoidine and, except for E. carotovora strains $5 \mathrm{X}$ and $8 \mathrm{X}$, were negative for indole production. These results are consistent with descriptions of soft-rotting Erwinia spp. (7). Reference strains reacted strongly with MAb E2 in an indirect ELISA except for A1042-1 which only gave a weak signal. Of these tests, four $(\mathrm{KOH}$, glucose fermentation, pectolytic ability, and MAb E2 reactivity) were subsequently used for presumptive identification of Erwinia spp. The indigoidine and indole tests were used to further differentiate E. chrysanthemi from subspecies of E. carotovora.

Characterization of bacterial strains. Among the 48 strains obtained from plant and irrigation water samples, 33 were gram-negative, fermented glucose, formed pits on CVP medium, reacted with MAb E2, and produced beige and flat colonies with dry consistencies on YDC medium and, therefore, were presumptively identified as Erwinia spp. (Table 2). Of these, 22 strains isolated from plants originally imported from Costa Rica and Honduras and 1 strain from Hawaiian irrigation water were also positive for both indigoidine and indole, suggesting that they were E. chrysanthemi. Seven of the remaining Erwinia strains were fermentative and pectolytic but negative for indigoidine and indole production, suggesting an E. carotovora identification (most likely E. carotovora subsp. carotovora). These strains were isolated from Honduran and Philippine plant samples and Hawaiian irrigation water. The final three fermentative and pectolytic strains (all isolated from irrigation water) were indigoidine negative and indole positive, presumptively identifying Erwinia spp.

Fifteen strains lacked some or all of the phenotypic characteristics necessary to be considered Erwinia spp. (data not shown). Two strains were identified by Biolog as Citrobacter farmeri, three were Pantoea agglomerans and four were identified as species in the genera Klebsiella, Pseudomonas, Pandoraea, and Oceanomonas. The remaining six strains could not be identified by Biolog.

Comparison of methods for strain identification. Data obtained from Biolog and partial 16S rDNA sequencing analysis are shown in Table 3 for 20 of 33 strains presumptively identified as $E$. chrysanthemi, E. carotovora, or an Erwinia sp. by bacteriological testing. Of the 15 non-Erwinia strains, 6 also were included in the comparison. All 13 strains presumptively identified as E. chrysanthemi based on initial bacteriological tests were identified as E. chrysanthemi by both Biolog and 16S rDNA sequencing. The seven strains identified as E. carotovora or an Erwinia sp. based on the initial tests were identified as either E. carotovora subsp. carotovora by Biolog and $E$. carotovora by $16 \mathrm{~S}$ rDNA sequencing (two strains), or as E. chrysanthemi by Biolog and an Erwinia sp. by $16 \mathrm{~S}$ rDNA sequencing (five strains). Of the six strains considered non-Erwinia spp. by bacteriological analysis, none had the same species identifications by Biolog and $16 \mathrm{~S}$ rDNA sequencing. Only the 13 strains identified as E. chrysanthemi by all three identification methods (bacteriological tests, Biolog, and 16S rDNA sequencing) produced the expected PCR

Table 1. Characterization of nine reference strains of Erwinia chrysanthemi, E. carotovora subsp. carotovora, and E. carotovora subsp. atroseptica

\begin{tabular}{|c|c|c|c|c|c|c|c|}
\hline Strain $^{a}$ & Origin (host) & Pathogen & $\mathbf{O} / \mathbf{F}^{\mathbf{b}}$ & $\mathrm{CVP}^{\mathrm{c}}$ & Indigoidine production ${ }^{d}$ & Indole $^{\mathrm{e}}$ & MAb E2 \\
\hline $1042-1$ & Hawaii (philodendron) & E. chrysanthemi & $\mathrm{F}$ & + & + & + & \pm \\
\hline A $1955^{\mathrm{g}}$ & Missouri (corn) & E. chrysanthemi & $\mathrm{F}$ & + & + & + & + \\
\hline $\mathrm{CC} 26$ & Hawaii (aglaonema) & E. carotovora subsp. carotovora & $\mathrm{F}$ & + & - & - & + \\
\hline $\mathrm{CC} 53^{\mathrm{h}}$ & Ohio (potato) & E. carotovora subsp. atroseptica & $\mathrm{F}$ & + & - & - & + \\
\hline $2 \mathrm{~B}$ & Hawaii (aglaonema) & E. carotovora & $\mathrm{F}$ & + & - & - & + \\
\hline $3 \mathrm{C}$ & Hawaii (aglaonema) & E. carotovora & $\mathrm{F}$ & + & - & - & + \\
\hline $4 \mathrm{C}$ & Hawaii (aglaonema) & E. carotovora & $\mathrm{F}$ & + & - & - & + \\
\hline $5 \mathrm{X}$ & Hawaii (aglaonema) & E. carotovora & $\mathrm{F}$ & + & - & + & + \\
\hline $8 X$ & Hawaii (aglaonema) & E. carotovora & $\mathrm{F}$ & + & - & + & + \\
\hline
\end{tabular}

a All strains were tested for pathogenicity on pineapple except CC53.

$\mathrm{b}$ Indicates fermentation (F) of glucose using Hugh-Leifson test (10).

${ }^{\mathrm{c}} \mathrm{CVP}=$ crystal violet sodium polypectate medium (5). A positive reaction $(+)$ indicates pectolytic enzyme activity that causes deep pits within $48 \mathrm{~h}$.

${ }^{\mathrm{d}}$ Positive (+) indicates production of blue-pigmented indigoidine on yeast dextrose calcium carbonate medium.

e Positive (+) indicates indole production (7).

${ }^{\mathrm{f}}$ Positive (+) reactions were greater than two times the negative control in an indirect enzyme-linked immunosorbent assay using monoclonal antibody $(\mathrm{MAb})$ E2. Weakly positive $( \pm)$ reactions gave values between that of the negative control and the positive reactions.

g Originally provided by A. Chatterjee as strain D5.

${ }^{\mathrm{h}}$ Originally provided by M. P. Starr as strain EA153.

Table 2. Characterization of 33 Erwinia spp. isolated from pineapple plants and from irrigation water sources for the field

\begin{tabular}{|c|c|c|c|c|c|c|c|}
\hline Origin $^{a}$ & Strains ${ }^{\mathbf{b}}$ & $\mathbf{O} / \mathbf{F}^{\mathrm{c}}$ & CVPd & $\begin{array}{l}\text { Indigoidine } \\
\text { production }^{\mathrm{e}}\end{array}$ & Indole $^{f}$ & $\begin{array}{c}\text { MAb } \\
\text { E2g }\end{array}$ & $\begin{array}{l}\text { Presumptive } \\
\text { identification }\end{array}$ \\
\hline $\begin{array}{l}\text { Costa Rica } \\
\text { (mature plants) }\end{array}$ & $\begin{array}{l}\text { A5264, A5266, A5268, A5270, A5272, A5274, A5292, } \\
\text { A5293, A5263, A5265, A5267, A5269, A5271 }\end{array}$ & $\mathrm{F}$ & + & + & + & + & E. chrysanthemi \\
\hline $\begin{array}{l}\text { Honduras } \\
\text { (mature plants) }\end{array}$ & $\begin{array}{l}\text { A5303, A5304, A5305, A5307, A5308, A5310, A5311, } \\
\text { A5306, A5309 } \\
\text { A5312 }\end{array}$ & $\mathrm{F}$ & + & + & + & + & E. chrysanthemi \\
\hline Philippines (suckers) & A5299, A5300, A5301, A5302, A5314 & $\mathrm{F}$ & + & - & - & + & E. carotovora \\
\hline Hawaii (water) & $\begin{array}{l}\text { A5277 } \\
\text { A5278 } \\
\text { A5276, A5279, A5280 }\end{array}$ & $\begin{array}{l}\mathrm{F} \\
\mathrm{F} \\
\mathrm{F}\end{array}$ & $\begin{array}{l}+ \\
+ \\
+\end{array}$ & $\begin{array}{l}+ \\
- \\
-\end{array}$ & $\begin{array}{l}+ \\
- \\
+\end{array}$ & $\begin{array}{l}+ \\
+ \\
+\end{array}$ & $\begin{array}{l}\text { E. chrysanthemi } \\
\text { E. carotovora } \\
\text { Erwinia } \text { sp. }\end{array}$ \\
\hline
\end{tabular}

a Types of tested material listed in parentheses.

b Strains in bold were tested for pathogenicity on pineapple leaves.

c Fermentation (F) of glucose using Hugh-Leifson test (10).

${ }^{\mathrm{d}} \mathrm{CVP}=$ crystal violet sodium polypectate medium (5). A positive reaction $(+)$ indicates pectolytic enzyme activity that causes deep pits within $48 \mathrm{~h}$.

e Positive (+) indicates production of blue-pigmented indigoidine on yeast dextrose calcium carbonate medium.

${ }^{f}$ Positive (+) indicates indole production (7).

$\mathrm{g}$ Positive (+) reactions were those greater than two times the negative control in an indirect enzyme-linked immunosorbent assay using monoclonal antibody (MAb) E2.

${ }^{\mathrm{h}}$ Identifications based on reactivity of the corresponding reference strains to the five phenotypic tests. 
product (400 to $450 \mathrm{bp}$ ) using the ADE1/ADE2 primer set (Table 3).

Rep-PCR fingerprinting analysis. Two bright bands (approximately 900 bp and $1.7 \mathrm{~kb}$ ) were shared by all E. chrysanthemi strains isolated from pineapple plants (Fig. 2, arrows, lanes 5-8) but were not present in the other E. chrysanthemi, E. carotovora, Erwinia sp., and non-Erwinia fingerprints. E. chrysanthemi strains from Costa Rican and Honduran pineapple plants possessed fingerprints that were different from E. chrysanthemi strains isolated from nonpineapple sources. Strains identified as $E$. carotovora, Erwinia sp., and the nonErwinia pineapple saprophytes originating from the Philippines also possessed distinctly different BOX-PCR fingerprint patterns than the $E$. chrysanthemi strains.

Pathogenicity assays. Inoculation of selected bacterial strains into hybrid pineapple leaves confirmed that only the E. chrysanthemi isolated from pineapple induced symptoms similar to those observed on the original affected plants. Fifteen E. chrysanthemi strains isolated from pineapple plants from Costa Rica and Honduras produced light brown, puffy, spreading watersoaked lesions within $36 \mathrm{~h}$ after inoculation, whereas the two E. chrysanthemi strains isolated from philodendron and irrigation water in Hawaii (A1042-1 and A5277, respectively) were nonpathogenic on pineapple. The eight E. carotovora and E. carotovora subsp. carotovora strains produced only dry necrotic lesions, which failed to spread beyond the inoculation site. None of the other six strains identified as non-Erwinia pineapple saprophytes produced symptoms. By 3 weeks, leaves inoculated with $E$. chrysanthemi isolated from pineapple exhibited distinct blisters and decayed in some instances whereas leaves inoculated with the other bacterial strains showed scarring but no further symptom development. Reisolation of $E$. chrysanthemi from symptomatic leaves completed Koch's postulates and confirmed the causal agent.

\section{DISCUSSION}

Using a minimal number of bacteriological tests along with ELISA, Biolog, $16 \mathrm{~S}$ rDNA sequence analysis, and PCR, $E$. chrysanthemi was identified as the causal agent of the rot observed on pineapple plants, and this confirmed the first reported outbreak of this pineapple disease in an established Hawaiian plantation (29). DNA-based identification methods were used for confirmation rather than initial identification because this was a new disease outbreak involving an uncharacterized pathogen which had to be distinguished from numerous saprophytes in an initial screen. Moreover, the published PCR primers (19) had not been evaluated on $E$. chrysanthemi strains from pineapple; therefore, the assay needed validation before it could be used to identify the pineapple pathogen.

Differentiation of E. chrysanthemi from other Erwinia spp. and non-Erwinia saprophytes was consistently accomplished by observations of colony morphology, the $\mathrm{KOH}$ test for presumptive gram differentiation (27), oxidation or fermentation of glucose, pectolytic activity on CVP medium (5), and indigoidine and indole production (7). Identity confirmation using Biolog, 16S rDNA sequence analysis, and PCR supported the findings of these tests for $E$. chrysanthemi, indicating that these phenotypic characteristics were adequate for a presumptive identification.

Although both indigoidine and indole production were useful in this study for differentiating $E$. chrysanthemi from $E$. carotovora subsp. carotovora, other Erwinia spp., and saprophytes, production of both compounds can be variable and should not be used alone to reliably distinguish E. chrysanthemi from E. carotovora subsp. carotovora. It has been reported that indigoidine production varies depending on strain and culture age $(8,26)$. In our study, one E. chrysanthemi strain (A5277, from irrigation water) showed no pigment production when first selected for characterization but began producing indigoidine after several cycles of subculturing on agar plates. Thus, a lack of blue pigment produced on YDC should not immediately rule out a presumptive E. chrysanthemi identification. Conversely, an indolepositive colony possessing Erwinia-like characteristics should not automatically identify a strain as E. chrysanthemi. In two studies of E. carotovora subsp. carotovora diversity, up to one-third of the strains originating from certain geographical re-

Table 3. Comparison of bacterial identifications obtained using Biolog and 16S rDNA sequencing analysis

\begin{tabular}{|c|c|c|c|c|c|c|}
\hline \multirow[b]{2}{*}{ Strain } & \multirow[b]{2}{*}{ Presumptive $^{c}$} & \multicolumn{2}{|l|}{ Biologa } & \multicolumn{2}{|c|}{$16 S$ rDNA $^{b}$} & \multirow[b]{2}{*}{ ADE1/ADE2 } \\
\hline & & Identification & Sim & Identification & Homology (\%) & \\
\hline A5263 & E. chrysanthemi & E. chrysanthemi & 0.85 & E. chrysanthemi & 97 & + \\
\hline A5264 & E. chrysanthemi & E. chrysanthemi & 0.85 & E. chrysanthemi & 98 & + \\
\hline A5265 & E. chrysanthemi & E. chrysanthemi & 0.77 & E. chrysanthemi & 98 & + \\
\hline A5266 & E. chrysanthemi & E. chrysanthemi & 0.77 & E. chrysanthemi & 99 & + \\
\hline A5268 & E. chrysanthemi & E. chrysanthemi & 0.71 & E. chrysanthemi & 99 & + \\
\hline A5269 & E. chrysanthemi & E. chrysanthemi & 0.80 & E. chrysanthemi & 99 & + \\
\hline A5271 & E. chrysanthemi & E. chrysanthemi & 0.77 & E. chrysanthemi & 98 & + \\
\hline A5272 & E. chrysanthemi & E. chrysanthemi & 0.56 & E. chrysanthemi & 98 & + \\
\hline A5277 & E. chrysanthemi & E. chrysanthemi & 0.81 & E. chrysanthemi & 98 & + \\
\hline A5304 & E. chrysanthemi & E. chrysanthemi & 0.77 & E. chrysanthemi & 97 & + \\
\hline A5307 & E. chrysanthemi & E. chrysanthemi & 0.62 & E. chrysanthemi & 99 & + \\
\hline A5310 & E. chrysanthemi & E. chrysanthemi & 0.60 & E. chrysanthemi & 99 & + \\
\hline A5292 & E. chrysanthemi & E. chrysanthemi & 0.72 & E. chrysanthemi & 98 & + \\
\hline A5278 & E. carotovora & E. carotovora subsp. carotovora & 0.58 & E. carotovora & 97 & - \\
\hline A5280 & Erwinia sp. & E. carotovora subsp. carotovora & 0.65 & E. carotovora & 98 & - \\
\hline A5299 & E. carotovora & E. chrysanthemi & 0.52 & Erwinia sp. & 99 & - \\
\hline A5314 & E. carotovora & (E. chrysanthemi) & 0.62 & Erwinia sp. & 99 & - \\
\hline A5300 & E. carotovora & E. chrysanthemi & 0.56 & Erwinia sp. & 99 & - \\
\hline A5301 & E. carotovora & E. chrysanthemi & 0.56 & Erwinia sp. & 98 & - \\
\hline A5302 & E. carotovora & E. chrysanthemi & 0.56 & Erwinia sp. & 98 & - \\
\hline A5315 & Non-Erwinia unknown & Citrobacter farmeri & 0.54 & Citrobacter sedlakii & 99 & - \\
\hline A5317 & Non-Erwinia unknown & Oceanomonas doudoroffii & 0.74 & Bordetella sp. & 94 & - \\
\hline A5318 & Non-Erwinia unknown & Pseudomonas resinovorans & 0.55 & Pseudomonas sp. & 100 & - \\
\hline A5319 & Non-Erwinia unknown & Pantoea agglomerans & 0.52 & Klebsiella oxytoca & 99 & - \\
\hline A5321 & Non-Erwinia unknown & (Pseudomonas maculicola) & 0.36 & Pseudomonas putida & 99 & - \\
\hline A5324 & Non-Erwinia unknown & (Brevibacterium otitidis) & 0.38 & Bacillus sp. & 100 & - \\
\hline
\end{tabular}

a Identifications obtained using the GN (version 6.01) or GP (version 6.11) databases. Similarity (sim) values approaching 1.0 indicate greater homology to reference strains in the Biolog database. Names in parentheses were the closest database match but indicate low similarity.

${ }^{\mathrm{b}}$ Identifications obtained by BLASTN search (database version 2.2.18). Percent homology given to the best named match returned for each strain.

c Presumptive identification determined using six phenotypic tests. 
gions were found to produce the compound $(25,32)$. Indole-positive strains were also seen in this study (E. carotovora reference strains $5 \mathrm{X}$ and $8 \mathrm{X}$ and presumptive Erwinia strains A5276, A5279, and A5280 from irrigation water). Therefore, indigoidine and indole production should be used only as part of a more comprehensive polyphasic identification scheme, because a positive with either in combination with the previous four tests adds confidence to a presumptive identification.

MAb E2 did not differentiate E. chrysanthemi and E. carotovora subsp. carotovora strains isolated from pineapple and also reacted with four strains that were not considered Erwinia spp. based on the bacteriological tests run in this study. Biolog eventually identified most of these nonErwinia strains as P. agglomerans-a species that now encompasses strains formerly classified as E. herbicola. Whether reactivity of MAb E2 with these strains is caused by a shared epitope among members of the current and former erwiniae or just a similar but different epitope remains unknown. Recently, additional MAbs have been generated using a pineapple E. chrysanthemi strain as immunogen and these are being screened to determine their potential for diagnostic use.

Identifications obtained from Biolog and 16S rDNA sequencing analysis were consistently in agreement with the bacteriological tests that presumptively identified strains as E. chrysanthemi. Confirmatory analysis of at least 1,200 bp from the $16 \mathrm{~S}$ rRNA gene of these 13 E. chrysanthemi strains indicated that the pineapple isolates shared 98 to $99 \%$ sequence homology to $E$. chrysanthemi strain ICMP 9288 (accession no.EF530559), whereas the single E. chrysanthemi strain from water shared $100 \%$ homology (1,263 bp) to E. chrysanthemi strain ICMP 9290 (accession no. EF530561). Partial 16S rRNA gene sequences of the representative strains A5264 and A5307 have been submitted to GenBank as accession numbers EU821583 and EU821584, respectively.

Of the seven strains that were presumptively identified as E. carotovora or an Erwinia sp. by bacteriological tests, only two also were confirmed as E. carotovora by both Biolog and $16 \mathrm{~S}$ rDNA sequencing (A5278 and A5280). In the other five instances, Biolog identified the strains as $E$. chrysanthemi whereas 16S rDNA sequencing only identified the strains to genus level. These results warn of the potential drawbacks in relying solely on one method for species identification of an unknown. In contrast, all 13 strains in Table 3 that were originally identified by bacteriological tests as E. chrysanthemi produced the expected band using the specific ADE1/ ADE2 primer set (19) and no PCR products were generated by pure cultures of the six E. carotovora strains or other saprophytes. With further validation using PCR directly on plant samples, the assay may prove useful for future field surveys.

Pathogenicity testing on low-acid hybrid pineapple plants and subsequent bacterial reisolations satisfied Koch's postulates and showed that only those E. chrysanthemi isolated from pineapple could cause the original symptoms when inoculated into that host. Additional pathogenicity tests to explore the host range of these strains are planned, including assays to determine the susceptibility of other pineapple cultivars. Host ranges of 13 E. chrysanthemi strains from pineapple have been studied (9), but it is not known whether the current strains share the same hosts or can infect other previously untested local crops.

The BOXA1R primer used in rep-PCR is complementary to one of three subunits in the BOX element, a conserved repetitive sequence present in high copy number on the chromosomes of both gram-negative and gram-positive organisms $(16,28)$. As such, it can be used to generate specific genetic fingerprints that can indicate the homogeneity or heterogeneity of a given bacterial population. Failure to detect a common band for all E. chrysanthemi strains in this study (pineapple and nonpineapple sources) was not unexpected, because the genomic heterogeneity of this species has been documented $(2,21)$. Nevertheless, in repeated analyses, similar BOX-PCR fingerprint banding patterns were seen among all the E. chrysanthemi strains isolated from pineapple that were different from those obtained from the three non-pineapple E. chrysanthemi strains. Even though the pathogenic $E$. chrysanthemi strains isolated from Central American pineapple plants possessed banding patterns that distinguished them from the local E. chrysanthemi strains, we cannot definitively conclude that the inoculum for the bacterial heart rot disease outbreak was of foreign origin because of

\section{E. chrysanthemi}

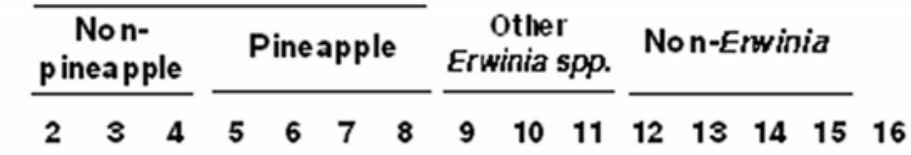

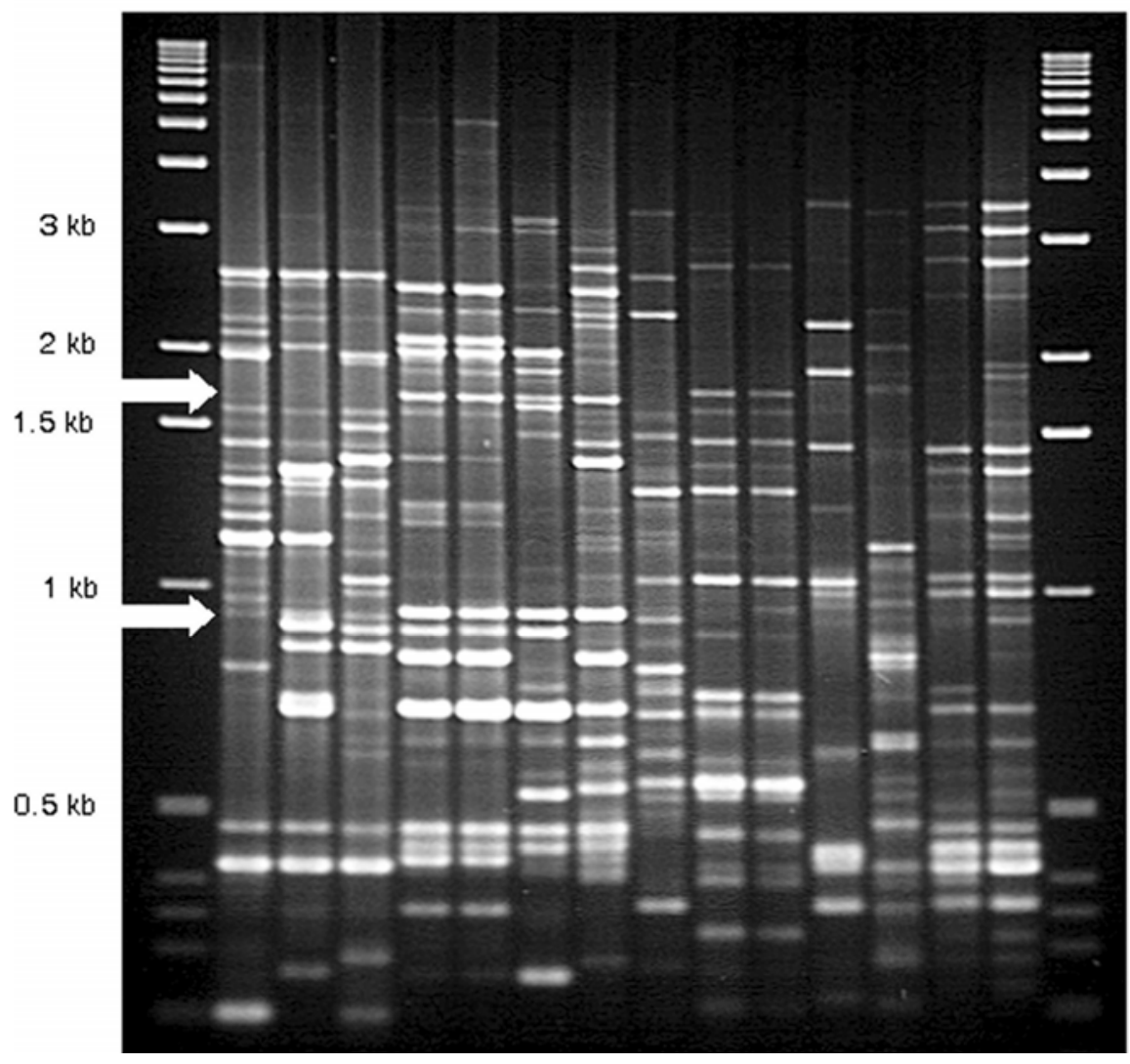

Fig. 2. Comparison of BOX-polymerase chain reaction DNA fingerprints from Erwinia chrysanthemi, E. carotovora, Erwinia sp., and non-Erwinia strains. Lanes 1 and 16 contain 1-kb markers. Lanes 2 and 3, reference E. chrysanthemi strains isolated from philodendron (A1042-1) and corn (A1955); lane 4, strain A5277 isolated from irrigation water in Hawaii; lanes 5-8, strains isolated from mature field plants originally imported from Costa Rica (A5292, A5272, and A5268) and Honduras (A5310) as planting stocks; lanes 9-11, a strain of Erwinia sp. isolated from irrigation water (A5280) and strains of E. carotovora isolated from pineapple suckers from the Philippines (A5300 and A5314); and lanes 12-15, various non-Erwinia strains isolated from Philippine suckers (A5319, A5323, A5325, and A5326). Arrows at approximately $900 \mathrm{bp}$ and $1.7 \mathrm{~kb}$ indicate common bands present in all E. chrysanthemi strains from pineapple plants. 
the small sample size used to represent the local E. chrysanthemi populations in the current study. However, the distinct fingerprint patterns exhibited by the pineapple $E$. chrysanthemi strains will be useful for monitoring strain movement through the environment for epidemiological purposes.

The panel of six phenotypic tests $(\mathrm{KOH}$, YDC colony morphology, O/F, pectolytic ability on CVP, indole production, and indigoidine production) allowed for consistent differentiation of $E$. chrysanthemi from other non-E. chrysanthemi strains isolated from pineapple. Although not particularly rapid, these tests provide a reliable scheme for identifying $E$. chrysanthemi from environmental and plant sources using non-species-specific identification tools. Current populations of $E$. chrysanthemi found on pineapple in Hawaii have now been defined and partially characterized, and the data collected are being used to develop new antibody-based and DNA-based rapid identification assays that will facilitate further investigation into the origin of the inoculum and tracking the populations in the environment. A comprehensive study, including further genetic comparisons among a larger collection of E. chrysanthemi strains from local ornamentals, Hawaiian soil and water, and pineapple stocks in countries of origin, is underway in an attempt to clarify the regulatory implications of these strains isolated from pineapple. Additional bacteriological and genetic characterization of the strains will also help to determine their placement within the Dickeya nomenclature.

\section{ACKNOWLEDGMENTS}

This work was partially funded by the United States Department of Agriculture (USDA)CSREES National Plant Diagnostic Network (Western Region) and the USDA Tropical and Subtropical Agricultural Research (T-STAR) program award no. 2004-34135-15195. We thank S. Garner for her technical assistance; G. Marrero for her contig assembly and alignment expertise; and D. Bartholomew, G. Peckham, D. Sether, and G. Taniguchi for their critical reviews of earlier manuscript versions.

\section{LITERATURE CITED}

1. Benedict, A. A., Alvarez, A. M., Berestecky, J., Imanaka, W., Mizumoto, C. Y., Pollard, L. W., Mew, T. W., and Gonzalez, C. F. 1989. Pathovar-specific monoclonal antibodies for Xanthomonas campestris pv. oryzae and for Xanthomonas campestris pv. oryzicola. Phytopathology 79:322-328.

2. Boccara, M., Vedel, R., Lalo, D., Lebrun, M.H., and Lafay, J. F. 1991. Genetic diversity and host range in strains of Erwinia chrysanthemi. Mol. Plant-Microbe Interact. 4:293-299.
3. Bradbury, J. F. 1986. Guide to Plant Pathogenic Bacteria. CAB International, Wallingford, UK.

4. Chinchilla, C. M., Gonzales, L. C., and Morales, F. 1979. Purdrición bacteriana del cogollo de la piña en Costa Rica. Agron. Costarric. 3:183-185.

5. Cuppels, D., and Kelman, A. 1974. Evaluation of selective media for isolation of soft-rot bacteria from soil and plant tissue. Phytopathology 64:468-475.

6. De Boer, S. H., and D'Aubin, J. M. 2005. Detection and differentiation of pectolytic erwinias in potato by multiplex PCR. Can. J. Plant Pathol. 27:162-163.

7. De Boer, S. H., and Kelman, A. 2001. Erwinia soft rot group. Pages 56-72 in: Laboratory Guide for Identification of Plant Pathogenic Bacteria, 3rd ed. N. W. Schaad, J. B. Jones, and W. Chun, eds. American Phytopathological Society Press, St. Paul, MN

8. Dickey, R. S. 1979. Erwinia chrysanthemi: A comparative study of phenotypic properties of strains from several hosts and other Erwinia species. Phytopathology 69:324-329.

9. Dickey, R. S. 1981. Erwinia chrysanthemi: Reaction of eight plant species to strains from several hosts and to strains of other Erwinia species. Phytopathology 71:23-29.

10. Hugh, R., and Leifson, E. 1953. The taxonomic significance of fermentative versus oxidative metabolism of carbohydrates by various gram negative bacteria. J. Bacteriol. 66:24-26.

11. Johnston, A. 1957. Bacterial heart rot of the pineapple. Malay. Agric. J. 40:2-8

12. Kelman, A. 1954. The relationship of pathogenicity in Pseudomonas solanacearum to colony appearance on a tetrazolium medium. Phytopathology 44:693-695.

13. Kwon, S.-W., Go, S.-J., Kang, H.-W., Ryu, J.C., and Jo, J.-K. 1997. Phylogenetic analysis of Erwinia species based on 16S rRNA gene sequences. Int. J. Syst. Bacteriol. 47:10611067.

14. Lim, W. H., and Lowings, P. H. 1979. Pineapple fruit collapse in peninsular Malaysia: symptoms and varietal susceptibility. Plant Dis. Rep. 63:170-174.

15. Louws, F. J., and Cuppels, D. A. 2001. Molecular techniques. Pages 321-337 in: Laboratory Guide for Identification of Plant Pathogenic Bacteria, 3rd ed. N. W. Schaad, J. B. Jones, and W. Chun, eds. American Phytopathological Society Press, St. Paul, MN.

16. Martin, B., Humbert, O., Camara, M., Guenzi, E., Walker, J., Mitchell, T., Andrew, P., Prudhomme, M., Alloing, G., Haknebeck, R., Morrison, D. A., Boulnois, G. J., and Claverys, J.P. 1992. A highly conserved repeated DNA element located in the chromosome of Streptococcus pneumoniae. Nucleic Acids Res. 20:3479-3483.

17. Miller, T. D., and Schroth, M. N. 1972. Monitoring the epiphytic population of Erwinia amylovora on pear with a selective medium. Phytopathology 62:1175-1182.

18. NASS (National Agricultural Statistics Service). 2007. Hawaii Pineapples. Released February 7, 2007.

19. Nassar, A., Darrasse, A., Lemattre, M., Kotoujansky, A., Dervin, C., Vedel, R., and Bertheau, Y. 1996. Characterization of Erwinia chrysan- themi by pectinolytic isozyme polymorphism and restriction fragment length polymorphism analysis of PCR-amplified fragments of pel genes. Appl. Environ. Microbiol. 62:2228 2235

20. Norman, D., and Alvarez, A. 1989. A rapid method for presumptive identification of Xanthomonas campestris pv. dieffenbachiae and other xanthomonads. Plant Dis. 73:654-658.

21. Norman, D. J., Yuen, J. M. F., Resendiz, R. and Boswell, J. 2003. Characterization of $\mathrm{Er}$ winia populations from nursery retention ponds and lakes infecting ornamental plants in Florida. Plant Dis. 87:193-196.

22. Perombelon, M. C. M., and Kelman, A. 1980. Ecology of the soft rot Erwinias. Annu. Rev. Phytopathol. 18:361-387.

23. Rohrbach, K. G., and Johnson, M. W. 2003. Pests, diseases and weeds. Pages 203-251 in The Pineapple: Botany, Production and Uses. D. P. Bartholomew, R. E. Paull, and K. G. Rohrbach, eds. CABI Publishing, Wallingford, UK.

24. Samson, R., Legendre, J. B., Christen, R., Fischer-Le Saux, M., Achouak, W., and Gardan, L. 2005. Transfer of Pectobacterium chry santhemi (Burkholder et al. 1953) Brenner et al. 1973 and Brenneria paradisiaca to the genus Dickeya gen. nov. as Dickeya chrysanthem comb. nov. and Dickeya paradisiaca comb. nov. and delineations of four novel species, Dickeya dadantii sp. nov., Dickeya dianthicola sp. nov., Dickeya dieffenbachiae sp. nov. and Dickeya zeae sp. nov. Int. J. Syst. Evol. Microbiol. 55:1415-1427.

25. Seo, S. T., Furuya, N., Lim, C. K., Takanami, Y., and Tsuchiya, K. 2002. Phenotypic and genetic diversity of Erwinia carotovora ssp. carotovora strains from Asia. J. Phytopathol. 150:120-127.

26. Starr, M. P., Cosens, G., and Knackmuss, H.-J. 1966. Formation of the blue pigment indigoidine by phytopathogenic Erwinia. Appl. Microbiol. 14:870-872.

27. Suslow, T. V., Schroth, M. N., and Isaka, M. 1982. Application of a rapid method for gram differentiation of plant pathogenic and saprophytic bacteria without staining. Phytopathology 72:917-918.

28. Versalovic, J., Schneider, M., de Bruijn, F. J., and Lupski, J. R. 1994. Genomic fingerprinting of bacteria using repetitive sequence-based polymerase chain reaction. Methods Mol. Cell Biol. 5:25-40.

29. Vine, B., Burger, M., Kaneshiro, W., de Silva, A., and Alvarez, A. 2005. Molecular characterization of bacterial strains to investigate the origin of pineapple heart rot disease in Hawaii. (Abstr.) Phytopathology 95:S107.

30. Weisburg, W. G., Barns, S. M., Pelletier, D. A. and Lane, D. J. 1991. 16S ribosomal DNA amplification for phylogenetic study. J. Bacteriol. 173:697-703.

31. Wilson, E. E., Zeitoun, F. M., and Fredrickson, D. L. 1967. Bacterial phloem canker, a new disease of Persian walnut trees. Phytopathology 57:618-621.

32. Yap, M. N., Barak, J. D., and Charkowski, A. O. 2004. Genomic diversity of Erwinia carotovora subsp. carotovora and its correlation with virulence. Appl. Environ. Microbiol. 70:30133023 